Peer-Reviewed Article

ISSN: 2162-3104 Print/ ISSN: 2166-3750 Online

Volume 7, Issue 2 (2017), pp. 395-420

(C) Journal of International Students

http://jistudents.org/

\title{
College Experiences and Outcomes Among International Undergraduate Students at Research Universities in the United States: A Comparison to Their Domestic Peers
}

\author{
Young K. Kim \\ Christopher S. Collins \\ Liz A. Rennick \\ Azusa Pacific University, USA
}

David Edens

California State Polytechnic University, Pomona, USA

\begin{abstract}
Using a large dataset from a state education system, this study examined the experience of international college students in the United States as well as the connection to their cognitive, affective, and civic outcomes. The study utilized data from the 2010 University of California Undergraduate Experience Survey (UCUES) and a sample of 35,146 junior and senior undergraduate students across 10 campuses. The results of this study showed that international students may uniquely experience college and may not benefit from those experiences as much as their domestic peers. Furthermore, this study identified a broad range of college experiences that contribute to the key outcomes for international students. The study discusses the theoretical and practical implications of the findings.
\end{abstract}

Keywords: International students, college experiences, college outcomes, research universities

Due to the increasing number of students who move across borders to study, international students draw much attention in the United States and in global discussions of higher education. This cross-border education often contributes substantially to institutional revenue. The Chronicle of Higher Education recently featured an article entitled, "Fess Up: Foreign Students are Cash Cows," which emphasized that tuition revenue is a primary interest 
when recruiting international students (Fischer, 2012). However, international students do not always recognize the financial motivation associated with their enrollment, and the revenues are rarely reinvested to create a better educational experience for these students. The Institute for International Education's annual Open Doors Report (Institute of International Education, 2013) estimated that international students contributed $\$ 24$ billion to the United States economy in the year 2013 alone. Although the United States is slowly losing dominance to Australia and Canada in terms of attracting international students, almost one third of students studying in a foreign country come to the United States. The massive opportunity for revenue has led several institutions to outsource overseas recruiting to agents who are paid commissions for acquiring applications and enrolling international students, which has created a market-oriented environment. Given the vast market and interest in international students, an ongoing question looms about their educational experiences and outcomes when compared to their domestic peers. For the purpose of this study, domestic students are defined as United States citizens or those with permanent resident status attending higher education institutions in the United States while international students are foreign students who are in the United States on a temporary basis (e.g., student visa) while attending a United States institution.

The tension between the market-driven pursuit of international students and the differences in educational experiences serve as the background for the purpose of this study, which is to improve our understanding of college experiences and outcomes of international students at research universities in the United States in comparison to their domestic counterparts. Using a statewide college student dataset, this study is designed to explore three research questions: (1) What are the differences between international college students and their domestic peers at United States research universities in the development of select college student outcomes over time? (2) What are the differences between international college students at these institutions and their domestic counterparts in the patterns of engagement in college experiences? (3) What college experiences predict select student outcomes among international college students at these institutions?

\section{BACKGROUND AND LITERATURE REVIEW}

\section{Cognitive Outcomes of College Students}

One of the main outcomes of a college education is students' cognitive or intellectual development. Although there has been a lack of evidence in the literature about the effect of the college experience on cognitive development (Pascarella \& Terenzini, 2005), some researchers 
have provided insight into how students develop cognitively in college. In general, students gain cognitive skills/abilities by attending college. Most notably, students' self-confidence increases in verbal skills, math skills, and critical thinking skills while attending college (Carini \& Kuh, 2003; Pascarella \& Terenzini, 2005; Volkwein, Valle, Parmely, Gary, \& Zhou, 2000). While these studies have examined a general influence of college attendance on students' cognitive development, other researchers have identified individual aspects of the college experience that affect student development in this area.

Perhaps academic engagement is among the most influential college experiences that contribute to college students' cognitive or intellectual development. When students are more engaged in their learning (e.g., attending more classes, investing more hours in studying, participating more frequently in classroom discussions), students obtain greater gains in their cognitive/intellectual outcomes (Astin, 1993; Harper \& Quayle, 2009; McCormick, Kinzie, \& Gonyea, 2013; Pascarella \& Terenzini, 2005). Also, students' academic engagement with their faculty members and peers facilitate their cognitive development over the college years (Kim \& Sax, 2009, 2011; McCormick, Kinzie, \& Gonyea, 2013; Umbach \& Wawrzynski, 2005).

Students' learning and development in college is also affected by both the structural diversity of the campus and the introduction of diversity topics into the curriculum. Studies found that students attending institutions that have higher levels of structural diversity (i.e., more heterogeneous student body) reported higher levels of learning and cognitive development compared to their counterparts who attended institutions with more homogenous student demographics (Chang, Witt, Jones, \& Hakuta, 2003; Cole, 2011). When diversity topics were more frequently introduced with the pedagogy and curriculum, students also tended to report higher levels of learning and cognitive growth (Gurin, Dey, Hurtado, \& Gurin, 2002).

Students' academic major field is another college experience that possibly affects their cognitive development during college. Research has demonstrated that college students' academic major tends to be associated with their levels of development in cognitive outcomes. Astin (1993) found that students who were in social science or humanities majors tended to report greater gains in their cognitive outcomes compared to their peers in other academic major fields. Similar results have been also noted by other studies that examined the relationship between students' academic major and cognitive development (Cole, 2007, 2011; Schreiner \& Kim, 2011; Strauss \& Volkwein, 2004).

Beyond the classroom environment, extracurricular activities have been shown to affect college students' cognitive development. Studies suggest that some extracurricular activities such as social interaction with peers and 
service learning projects seem to be positively related to larger growth in cognitive and intellectual outcomes among college students (Busseri, et al, 2010; Cleg, Stevenson, \& Willcott, 2010; Gellen, 2003; Tieu \& Pancer, 2009; Tieu, et al, 2010). Conversely, other studies have found that participation in athletics and membership in a fraternity or sorority tended to have a negative effect on college students' cognitive development (Astin, 1993; Tieu \& Pancer, 2009). When it comes to work experience, some mixed findings exist in the literature. Pascarella \& Terenzini (2005) noted that work experience, either on- or off-campus, had little effect on student learning and cognitive outcomes development. However, Lundberg and Schreiner (2004) noted that student learning was negatively affected by their off-campus work experience.

\section{Affective Outcomes of College Students}

Considering that college is a social (as well as academic) environment, affective outcomes are another set of desirable college outcomes. Research has shown that college's sub-environments such as students' academic majors, departments, or disciplines, have often created unique social environments for students and that various types of interactions with socializing agents (e.g., faculty, staff, peers) have enhanced students' development in affective outcomes, including interpersonal skills, leadership skills, and college satisfaction (Rubin, Bommer, \& Baldwin, 2002; Umbach \& Wawrzynski, 2005; Vowell, 2007). Furthermore, studies noted that certain pre-college characteristics such as student gender, race, and socioeconomic status also affect the development of interpersonal skills among college students (Hausmann, Schofield, \& Woods, 2007; Hausmann, Ye, Schofield, \& Woods, 2009; Ostrove \& Long, 2007).

The pedagogy of classes, working with faculty, and studying with peers are also related to students' affective development. For example, Astin (1993) found that certain classroom activities such as group projects and presentations tended to improve students' sense of leadership, a specific domain of affective development. Studies have also shown that meeting/working with faculty, such as discussing ideas and attending conferences and workshops, were positively associated with interpersonal skills development among college students (Astin, 1993; Elkins, Forrester, \& Noel-Elkins, 2011; Sax, 2008; Strayhorn, 2012).

\section{Civic Outcomes of College Students}

One of the major goals of a college education is to develop a student as a member of the greater community (Sax, 2000). Early research on the civic outcomes of college students found a significant, positive relationship between students' college experience and their humanitarian values (Pascarella, Ethington, \& Smart, 1988; Rockenbach, Hudson, \& Tuchmayer, 2014). Astin (1993) also noted that students' experiences in college affected 
their social values and involvement in community action programs, as well as how students participated in the political process and promotion of racial understanding. Similarly, Lopez and Kiesa (2009) found that college attendance was positively associated with voter turnout in elections and volunteerism within the community.

Beyond the college attendance, some studies have also identified the specific college experiences that contributed to students' development in civic outcomes. Studies have shown that classroom experiences integrated with community service and faculty interactions positively affected students' civic engagement and outcomes (Astin, 1993; Hurtado, Ruiz, \& Whang, 2012; Lott, 2013). Research also found some significant relationships between students' academic major and their civic engagement. Students majoring in the social sciences tend to report higher levels of civic engagement during college as compared to their peers in other academic major fields (Lott, 2013; Pascarella, Ethington, \& Smart, 1988; Schreiner \& Kim, 2013), while students in STEM majors have often shown lower levels of civic engagement (Astin, 1993; Rhee \& Dey, 1996; Sax, 2000).

\section{College Outcomes and Experience of International Student}

While higher education literature has well documented the net effects of college attendance on students' growth or development in affective, cognitive, and civic outcomes, the vast majority of the studies have focused on domestic college students, relatively ignoring the examination of such college effects on the international student population. However, given the increasing number of international college students in the United States and the lack of institutional support systems for this population, it is imperative to improve our understanding of college outcomes and experiences among international students.

Although some studies of international students' perceptions suggest that students admire the academic culture in the United States (Chow, 2011), other investigations indicate that international students face difficulties in an environment for which they have not been prepared (Bauer, 1998; Fischer, 2011; Harper \& Hurtado, 2007). Several recurring difficulties for international students have included country of origin (related to language and culture), lack of social support from host country nationals, difficulty in socializing, and associated negative experiences (HechanovaAlampay, Beehr, Christiansen, \& Van Horn, 2002; Lee \& Rice, 2007; Mori, 2000). Li (2012) found that the primary needs of international students were psychological, linguistic-academic, and sociocultural. International students often battle feelings of isolation from familiar surroundings, challenges associated with the combination of demands on their academic skills, and the need to experience the host culture. Bartram (2008) demonstrated that 
international students have distinct needs that are related to cultural barriers when compared to their domestic peers that are related to cultural barriers.

Literature on international students' experiences has often attributed international students' difficulties to the need to adapt, transition, and cope, implying that the burden is on the students to overcome and integrate into the host culture (Bevis, 2002; Klineberg \& Hull, 1979; Pritchard \& Skinner, 2002; Zhao, Kuh, \& Carini, 2005). In one study, students who adapted to the host culture were portrayed as having developed greater intercultural competence (Pritchard \& Skinner, 2002); another study associated difficulties with the lack of assimilation to American culture (Al-Sharideh \& Goe, 1998). Framing negative international students' experiences as an issue of personal responsibility carries an underlying assumption that the host campus and country do not play a role in contributing to the exclusion or marginalization of these students. For example, some studies have outlined how Chinese students in particular have experienced a gap between expectations and reality and, ultimately, an unsupportive educational environment that could be perceived as exploitation (Li \& Collins, 2014; Ho \& Ho, 2008; Zhao, Kuh, \& Carini, 2005).

However, Lee (2010) found that perceived discrimination, quality of campus services, and financial difficulties were highly influential in international students' attitudes about their United States educational experience. Studies have shown that non-Western students studying in Western societies like the United States experienced a kind of neoracism, which Lee (2007) defined as "discrimination based on culture and national order" (p. 389). Given the increased focus on diversity in higher education following post World War II massification, any special focus on equity for international students has been seen as suspect because the students are voluntary minorities. Lee (2010), however, critically challenged institutions to engage with international students in meaningful ways and "value them as vital contributors to international exchange and diplomacy" (p. 77).

\section{THEORETICAL FRAMEWORKS}

The conceptual and theoretical frameworks used to guide this study are based on Astin's (1993) Input-Environment-Outcomes (I-E-O) model and Schlossberg's transition theory (Schlossberg, Waters, \& Goodman, 1995). Using Astin's (1993) I-E-O model as a conceptual framework of the study, we address the unique effect of college experiences on college students' development in cognitive, affective, and civic outcomes by minimizing the confounding effects of student inputs. Also, the current study assumes that international students have a unique set of college experiences that impact their development. Particularly, we hypothesize that international students are transitioning into a new country and a new culture, as well as their new 
college environment; the degree to which an individual can cope with transitions is dependent upon the resources available and the individual's utilization of those resources. We employ Schlossberg's transition theory to explain the possible impact of transitions on international students' college experiences and outcomes.

\section{RESEARCH METHOD}

\section{Data Source and Sample}

For this study, we utilized data from the 2010 University of California Undergraduate Experience Survey (UCUES). The survey instrument is administered to all students system-wide (i.e., all ten UC campuses) on a biennial basis though the Office of Student Research and Campus Surveys at UC Berkeley, with support from the UC Office of the President. The UCUES collects information on a broad range of educational experiences, including academic and co-curricular activities, instruction, advising, and student services, as well as student background characteristics, academic and personal development, and evaluation of the academic majors (Brint, Douglass, Flacks, Thomson, \& Chatman, 2007). The UCUES 2010 population includes all undergraduate students at 10 UC campuses who were enrolled in winter quarter 2010 or spring semester 2010 (at Berkeley and Merced). The response rate for the 2010 survey was $43 \%$, yielding 74,410 cases. Because this study was designed to examine student development or gains in select college outcomes over the college years, we limited our sample to only junior and senior students $(n=35,146)$ who had been fully exposed to college experiences. Within that sample, $917(2.6 \%)$ students were identified as international students while 34,229 (97.4\%) were identified as domestic students.

The student characteristics between the two samples varied. Among the domestic students in the sample, a majority of the participants selfidentified as Asian, Pacific Islander, or Filipino (41.6\%) or White (35.5\%), while a smaller number of students identified as Chicano or Latino (15.2\%), African American (5.3\%), American Indian or Alaskan Native $(0.7 \%)$ or some other race/ethnicity $(1.7 \%)$. Nationality or ethnicity of international students was not included in the dataset. The sample of international students consisted of $39.5 \%$ female students and $37.4 \%$ male students while the domestic student sample consisted of $48.4 \%$ female students and $34.1 \%$ male students. When it comes to socioeconomic status, the international student sample was $12.8 \%$ working class or low income, $38.8 \%$ middle class, and $27.9 \%$ wealthy, upper middle, or professional class while the domestic sample was made up of $31 \%$ working class or low income, $33.2 \%$ middle class, and $20.2 \%$ wealthy, upper middle, or professional class. More domestic students (20\%) were first-generation college students (i.e., neither 
parent had attained more than a high school degree) than international students $(15.6 \%)$. There was a wide gap between students with transfer student status: $61 \%$ of the international sample were transfer students while $25.4 \%$ of the domestic sample were transfer students.

\section{Variables}

The dependent variables of this study included three variables, each of which represented cognitive, affective, and civic outcomes among college students, respectively: (1) cognitive skills, (2) interpersonal skills, and (3) civic attitudes. Cognitive skills was a five-item factor scale that included individual survey items that asked students to rate their current cognitive abilities in five areas: (1) analytical and critical thinking skills, (2) ability to read and comprehend academic material, (3) ability to be clear and effective when writing, (4) understanding of a specific field of study, and (5) ability to speak clearly and effectively in English (Chronbach's alpha $=.85$ ). Interpersonal skills was an individual item on the UCUES survey that asked students to rate their current ability in interpersonal or social skills. Civic attitudes was a three-item factor scale that included individual survey items that asked students to rate their current civic ability to (1) appreciate, tolerate, and understand racial and ethnic diversity, (2) appreciate cultural and global diversity, and (3) understand the importance of personal social responsibility (Chronbach's alpha $=.84$ ).

Independent variables of this study included pretest measures, students' demographic and background characteristics, academic disciplines, and college experiences. The pretest measures represent students' self-assessment of their cognitive, affective, and civic abilities when they entered the college in the same survey items as the dependent variables (See Table 1 for factor loadings and internal consistency on composite outcome and pretest measures). Students' demographic and background variables included gender, socioeconomic status, language heritage, and transfer status. Students' academic disciplines were organized into five major categories: (1) arts and humanities, (2) engineering and computer sciences, (3) physical and biological sciences, (4) social sciences, and (5) professional schools. This study also included a broad range of college experiences that might have possibly affected our dependent variables. Those college experience variables were organized into four distinct categories: (1) satisfaction (i.e., satisfaction with the quality of instruction and courses in the major, academic advising and communication with faculty), (2) faculty involvement (i.e., academic engagement with faculty, involvement with faculty research), (3) learning involvement (i.e., critical reasoning classroom activity, curricular foundations for reasoning, elevated academic effort), and (4) peer involvement (i.e., participation in clubs or organizations, collaborative work on class projects). These college 
experience variables included both individual survey items and factor scales. Refer to Appendices A and B for coding schemes and variable definitions of all variables used in this study.

\section{Analysis}

Data analysis for this study was conducted using IBM SPSS Statistics 22. Prior to the main data analysis, data cleaning techniques were employed to remove outliers and ensure data normality, linearity, and homoscedasticity. To examine the differences in the development of select college student outcomes between international and domestic college students, we computed gains (changes) from pretest and posttest measures and analyzed them with independent samples $t$-tests. In addition, we conducted paired-samples $t$-tests on the pretest and posttest scores to see if the longitudinal gains (changes) were statistically significant. Next, to examine the differences in the patterns of engagement in college experiences between international and domestic students, we conducted independent samples $t$-tests (for continuous variables) and cross-tabulations with Chi-square tests (for categorical variables). Finally, to examine the predictors of select student outcomes among international students, we conducted a series of hierarchical multiple regression analyses on each of our three dependent variables. The independent variables for the regression analyses were organized into temporal blocks according to Astin's (1993) IE-O model in the following order: (1) pretest measure, (2) students' entering characteristics, (3) academic discipline, and (4) college experiences.

\section{RESULTS}

\section{Patterns of College Outcomes}

We first examined if the patterns in the development of select college outcomes over time were different between international college students and their domestic peers at United States research universities. The results in Table 2 show that while international students experienced significant gains in all select cognitive, affective, and civic outcomes over the college years, there were some statistically significant differences in terms of the magnitude of the gains when compared to their domestic peers. Specifically, international students experienced less gains than their domestic peers in interpersonal skills $(t=3.06, p<.01)$ during their college years, whereas they seemed to obtain statistically equivalent gains to their domestic counterparts in cognitive skills and civic attitudes. Also, compared to domestic students, international students reported lower mean scores for all three outcome measures of the study (i.e., cognitive skills, interpersonal skills, and civic attitudes) both in their freshman year and in their junior or senior year. 
Table 1: Factor Loadings and Internal Consistency on Composite Outcome Measures

Factor and Survey Items

Factor Internal

Loading Consistency $(\alpha)$

Cognitive Skills Factor Scale: Posttest

Please rate your current level of proficiency in

the following areas:

Analytical and critical thinking skills

Ability to read and comprehend academic material

Ability to be clear and effective when

writing

Understanding of a specific field of study

Ability to speak clearly and effectively in English

Cognitive Skills Factor Scale: Pretest

Please rate your level of proficiency in the following areas when you started at this campus:

Analytical and critical thinking skills

Ability to read and comprehend academic material

Ability to be clear and effective when

writing

Understanding of a specific field of study

Ability to speak clearly and effectively in

English

Civic Attitudes Factor Scale: Posttest

Please rate your current level of proficiency in the following areas:

Ability to appreciate, tolerate and

understand racial and ethnic diversity

Ability to appreciate cultural and global

diversity

Understanding the importance of personal social responsibility

Civic Attitudes Factor Scale: Pretest

Please rate your level of proficiency in the

following areas when you started at this campus:

Ability to appreciate, tolerate and

understand racial and ethnic diversity

Ability to appreciate cultural and global

diversity

Understanding the importance of personal social responsibility 
Table 2: Differences in Gains for Cognitive, Affective, and Civic Student Outcomes Between Domestic and International Students

\begin{tabular}{|c|c|c|c|c|c|c|}
\hline \multirow[b]{2}{*}{ Student Outcomes } & \multicolumn{2}{|c|}{$\begin{array}{l}\text { Mean Score in } \\
\text { Freshman Year }\end{array}$} & \multicolumn{2}{|c|}{$\begin{array}{c}\text { Mean Score in } \\
\text { Junior or Senior } \\
\text { Year }\end{array}$} & \multicolumn{2}{|c|}{$\begin{array}{l}\text { Mean Change } \\
\text { (Gains) }\end{array}$} \\
\hline & $\begin{array}{c}\text { Dome } \\
\text { stic }\end{array}$ & $\begin{array}{c}\text { Internati } \\
\text { onal }\end{array}$ & $\begin{array}{c}\text { Dome } \\
\text { stic }\end{array}$ & $\begin{array}{c}\text { Internati } \\
\text { onal }\end{array}$ & $\begin{array}{l}\text { Domest } \\
\text { ic } \\
\end{array}$ & $\begin{array}{c}\text { Internatio } \\
\text { nal }\end{array}$ \\
\hline $\begin{array}{l}\text { Cognitive Skills } \\
\text { Scale }\end{array}$ & 4.01 & 3.51 & 4.80 & 4.30 & .79 & .79 \\
\hline $\begin{array}{l}\text { Interpersonal } \\
\text { skills }\end{array}$ & 4.05 & 3.71 & 4.71 & 4.25 & .66 & .54 \\
\hline $\begin{array}{l}\text { Civic Outcomes } \\
\text { Scale }\end{array}$ & 4.50 & 4.16 & 5.03 & 4.65 & .53 & .49 \\
\hline
\end{tabular}

Note 1: Paired samples $t$-tests show that all longitudinal changes were significant $(p$ $<.001)$ across racial subgroups. $t$-scores varied by international student status as follows: Domestic (83.12 - 199.74); International (13.57 - 29.36).

Note 2: Independent samples $t$-tests indicate significant mean change differences between groups in interpersonal skills $(t=3.06, p<.01)$ only.

Note 3: Sample sizes for each group varied depending on the outcome measure. The sample size ranges were as follows: Domestic $(28,471-29,004)$; International (703-718).

\section{Patterns of College Experiences}

In terms of patterns of engagement in college activities, we could observe statistically significant differences between international students and their domestic peers in the domains of student satisfaction and learning involvement (see Table 3). Compared to their domestic peers, international students tended to report less satisfaction with the quality of instruction and courses in their major $(t=6.38, p<.001)$ and with academic advising and communication with faculty $(t=4.49, p<.001)$. In other words, international students were, on average, less satisfied than domestic students with the quality of lower- and upper-division courses, faculty instruction, and teaching by graduate student teaching assistants. International students were also less satisfied than their domestic counterparts with advising on academic matters by faculty, peer advisors, and college or departmental staff. In addition, they were less satisfied with faculty channels of communication, fair and equitable treatment by faculty, and faculty feedback on students' work.

When it comes to learning involvement, international students tended to report relatively lower levels of learning involvement than their domestic peers in critical reasoning classroom activity $(t=6.39, p<.001)$ and in curricular foundations for reasoning $(t=7.98, p<.001)$. International 
students reported a lower frequency in the academic requirements of such activities. In other words, compared to their domestic peers, international students seemed to perceive less institutional emphasis on cognitive activities, such as recalling specific facts, terms and concepts, as well as higher-order cognitive activities such as judging the value of information, ideas, actions, and conclusions based on the soundness of sources, methods, and reasoning.

\section{Table 3: Patterns of College Experiences by International Student Status}

\begin{tabular}{|c|c|c|c|c|}
\hline \multirow[b]{2}{*}{ Factor Scale Items } & \multicolumn{2}{|c|}{ Percentage/Mean } & \multirow{2}{*}{$t$} & \multirow{2}{*}{$\chi^{2}$} \\
\hline & Domestic & $\begin{array}{l}\text { Internation } \\
\text { al }\end{array}$ & & \\
\hline \multicolumn{5}{|l|}{ Satisfaction } \\
\hline $\begin{array}{l}\text { Satisfaction with the quality of } \\
\text { instruction and courses in the major }\end{array}$ & 5.04 & 4.58 & $6.38^{*}$ & \\
\hline $\begin{array}{l}\text { Satisfaction with academic } \\
\text { advising }\end{array}$ & 5.10 & 4.80 & $4.49 *$ & \\
\hline $\begin{array}{l}\quad \text { and communication with } \\
\text { faculty } \\
\text { Faculty Involvement }\end{array}$ & & & & \\
\hline Academic engagement with faculty & 2.65 & 2.63 & .93 & \\
\hline Involvement in research projects ${ }^{\dagger}$ & $31.6 \%$ & $31.9 \%$ & & 2.04 \\
\hline \multicolumn{5}{|l|}{ Learning Involvement } \\
\hline $\begin{array}{lll}\text { Critical } & \text { reasoning } & \text { classroom } \\
\text { activity } & & \end{array}$ & 4.90 & 4.42 & $6.39 *$ & \\
\hline Curricular foundation for reasoning & 4.95 & 4.30 & $7.98^{*}$ & \\
\hline Elevated academic effort & 4.93 & 4.96 & .91 & \\
\hline \multicolumn{5}{|l|}{ Peer Involvement } \\
\hline Collaborative work & 4.80 & 4.78 & 1.37 & \\
\hline Participation in clubs/organizations ${ }^{\dagger}$ & $58.0 \%$ & $59.5 \%$ & & 2.92 \\
\hline
\end{tabular}

${ }^{*} p<.001$

'Items are dichotomous measures

Note: Sample sizes for each subgroup varied depending on the outcome measure. The sample size ranges are as follows: Domestic $(29,260-26,406)$; International $(676-740)$.

\section{Predictors of College Outcomes}

In this study, we were also interested in identifying college experiences that contributed to gains or development in cognitive skills, interpersonal skills, and civic attitudes among international college students. To address this question, we conducted a series of hierarchical multiple 
regression analyses. Table 4 summarizes the results of the analyses. The adjusted $R^{2}$ for each regression model ranged between .42 and .58. In general, results indicated that most college experiences had positive relationships to at least one of the selected outcomes, while some other college experiences were not statistically related to any of the college outcomes and were not included in the final analyses. In addition, some aspects of faculty involvement and learning involvement positively predicted all three outcome measures while other college experiences had more mixed relationships with the outcome measures.

Satisfaction. There were mixed results with regard to the relationship between college satisfaction and our college outcome measures among international students. The results show that satisfaction with advising and out-of-class contact was not significantly related to any of the select outcomes for international college students. However, satisfaction with the quality of instruction and courses in the major was a positive predictor of cognitive skills $(\beta=.16, p<.001)$ for this population. This result would seem to indicate the importance of international student satisfaction with the quality of courses in the major (both lower and upper division), faculty instruction, and teaching by graduate student teaching assistants. When international students were satisfied with these aspects of college, they also reported a higher level of cognitive skills development, such as analytical and critical thinking, ability to read and comprehend academic material, and ability to be clear and effective when writing.

Faculty involvement. There were similar mixed results when it came to the effects of faculty involvement on the select college outcomes. Our results indicated that participation in faculty research did not have any statistically significant effect on the select outcomes. However, other forms of academic engagement with faculty (such as talking with faculty outside of class, interacting with faculty during class, and communicating with faculty by email or in person) were shown to positively affect all three select outcomes. Among international college-goers, students who had higher levels of such academic engagement with faculty tended to report higher levels of cognitive skills $(\beta=.11, p<.001)$, interpersonal skills $(\beta=.16, p<$ $.001)$, and civic attitudes $(\beta=.08, p<.01)$ in their junior or senior year, even after taking into account their initial levels in these outcome areas and the confounding effects of other college experiences.

Learning involvement. Learning involvement seems to have the most positive and consistent effects across the select outcome measures. The results revealed that students' engagement in critical reasoning classroom activity was positively associated with all three outcome measures of this 
study $(\beta=.09, p<.01$ for cognitive skills; $\beta=.12, p<.001$ interpersonal skills; and $\beta=.11, p<.001$ for civic attitudes).

\section{Table 4: Results of Regression Analyses on College Student Outcomes Among International Students}

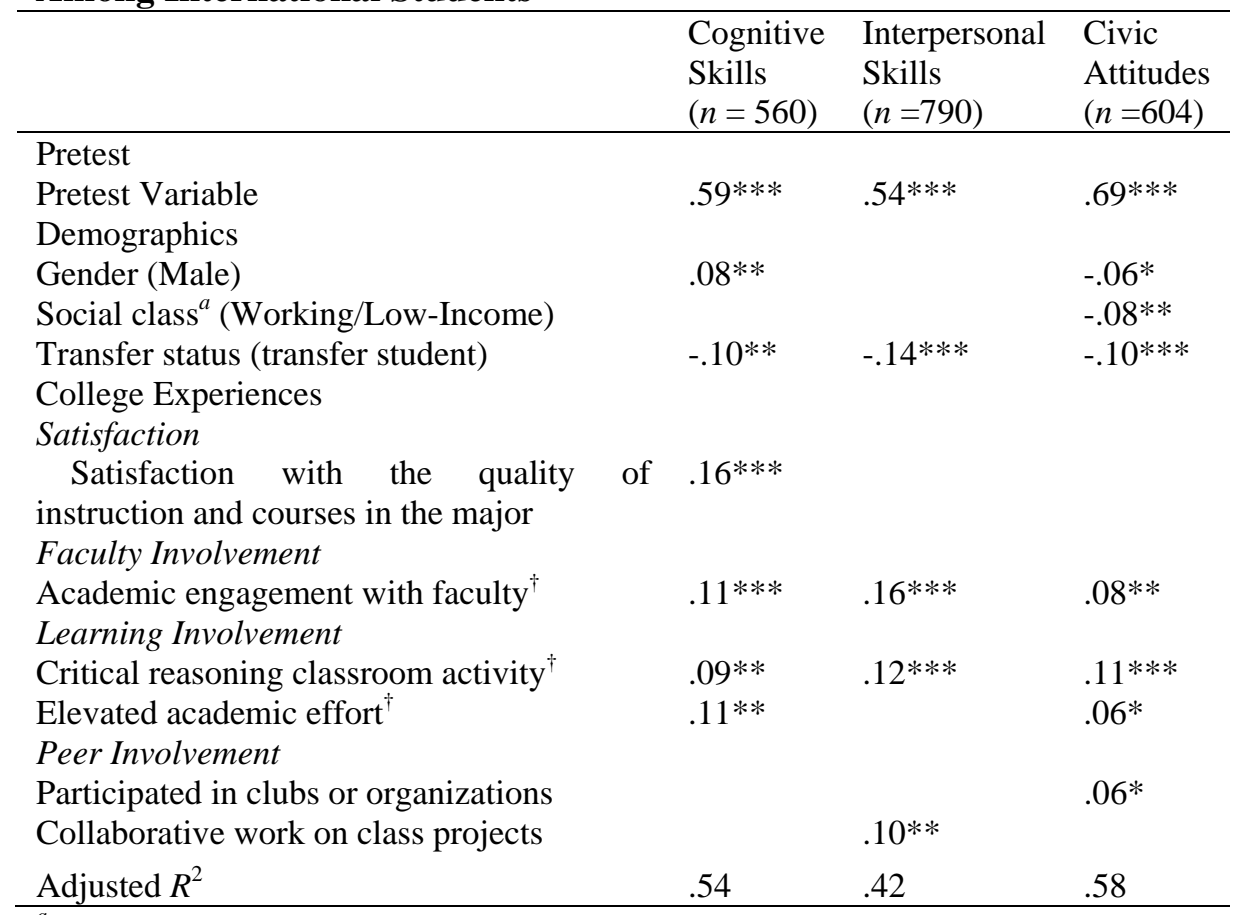

${ }^{a}$ Reference $=$ Professional Class/Wealthy

$* p<.05, * * p<.01, * * * p<.001$

In other words, international students who were more frequently engaged in critical reasoning classroom activities (such as judging the value of information based on the soundness of resources and creating new ideas or new ways of understanding) obtained greater gains in their cognitive skills, interpersonal skills, and civic attitudes over the college years compared to those students who were less engaged in critical reasoning classroom activities. Students' elevated academic effort was also positively associated with their gains in both cognitive skills $(\beta=.11, p<.01)$ and civic attitudes $(\beta=.06, p<.05)$. In other words, international students who demonstrated greater academic effort (e.g., raised their standards for acceptable effort due to the high standards of faculty, and extensively revised papers at least once before submitting for a grade) experienced larger growth in their cognitive skills and civic attitudes during their college years compared to their peers who indicated less academic effort. 
Peer involvement. Results show that students' participation in student clubs or organizations was positively related to the growth in civic attitudes for international students $(\beta=.06, p<.05)$. This result indicates that international students who participated in student clubs or organizations were more likely to adopt meaningful civic attitudes, such as elevated levels of understanding and appreciation of racial and ethnic diversity, cultural and global diversity, and the importance of social responsibility compared to international students who did not participate in clubs or organizations. In addition, working collaboratively with other students on a classroom project had a positive impact on the development of interpersonal skills for international students $(\beta=.10, p<.01)$.

Although not the main focus of this study, it is also worth mentioning how students' entering characteristics and college experiences were related to each of the outcomes for international students. When it comes to entering student characteristics, it appears that male international students obtained greater gains in cognitive skills $(\beta=.08, p<.01)$ than their female international peers, while female international students obtained greater gains in civic attitudes compared to their male counterparts $(\beta=-.06$, $p<.05)$. In terms of students' socioeconomic status in relationship with college outcomes, working class or low-income international students experienced less gains in civic attitudes $(\beta=-.08, p<.01)$ compared to professional class or higher-income (wealthy) international students. Transfer status was found to have a negative relationship with all outcome measures, suggesting that transfer students seemed to obtain fewer gains in cognitive, affective, and civic outcomes over the college years compared to their first-time student peers. When it comes to academic majors, our results indicated that there was no statistically significant relationship between any of academic majors and the select college outcomes of this study; hence, the academic major variables block was removed from the final regression equations.

\section{DISCUSSION AND IMPLICATIONS}

Set in the context of a research university system in the United States, this study examined the patterns of cognitive, affective, and civic outcomes development among international students as compared to those of their domestic peers and the predictors of these outcomes for international students. Overall, this study found that both international and domestic students experienced significant gains in all three domains of development during their college years. However, international students experienced significantly less gains in interpersonal skills during their college years compared to their domestic peers. International students often insulate themselves from the greater campus community and face problems such as 
isolation, loneliness, and lower levels of satisfaction (Al-Sharideh \& Goe, 1998). Beyond isolation, language proficiency can also be a factor that hinders international students' greater development in interpersonal skills. International students often face language barrier issues when interacting with their socializing agents on campus, which may cause additional reasons to keep these students from integrating with the greater campus community (Lee, 2010).

Another pattern we found in college outcomes of international students is that this population reported relatively lower mean scores for all of three outcomes, both in their freshman and junior/senior years, compared to their domestic peers. Given this discrepancy, college faculty and administrators should pay particular attention to programs that support learning and development of international students. The multiple regression analysis in this study showed that academic engagement with faculty and high order cognitive activities during class are the key areas that can enrich the international students' experiences and yield better results in all of the three outcomes. Therefore, higher education institutions and their members need to acknowledge the importance of these institutional practices to international students and should provide college environments where these students can fully engage in those practices.

In this study, international students also reported less satisfaction with the quality of instruction and courses in their major and with academic advising and communication with faculty than their domestic peers. Student satisfaction is one of the desirable outcomes of college students because it tends to be significantly related to other meaningful outcomes, such as retention, persistence, and academic engagement (Edens, 2011; Kuh, Kinzie, Buckley, Bridges, \& Hayek, 2006; Suhre, Jansen, \& Harskamp, 2007; Schreiner \& Louis, 2006, 2008). Specifically, researchers have found that satisfaction with advising was the strongest positive predictor of cognitive skills development among international students (Kim, Edens, Iorio, Curtis, \& Romero, 2015). Given the importance of student satisfaction as related to other college outcomes and the lower levels of academic satisfaction among international students compared to their domestic peers, higher education academia and professionals need to pay greater attention to international student's psychological well-being, including college satisfaction as they consider how they can best serve this population.

Another key finding of this study is that international students reported relatively lower levels of engagement in higher-order cognitive activities during class, such as critical reasoning/problem-solving, compared to their domestic peers. This finding is consistent with previous research on international students (Kim, et al., 2015). It appears from the findings of this and other studies (Kim, et al., 2015; Lee \& Rice, 2007) that international students benefit most from individual academic activities beyond the 
classroom environment. On the other hand, while international students reported lower levels of engagement in higher-order cognitive activities as compared to their peers, our results from the regression analyses showed that these activities were significant, positive predictors of all three outcomes (cognitive, affective, and civic outcomes) among international students. These findings point out the need for further studies on why international students might be hindered from engaging in high-order cognitive activities and what types of institutional interventions can facilitate higher levels of engagement in these activities.

Consistent with previous findings, the results of this study also showed that academic engagement with faculty was positively associated with all three select outcomes of the study. Studies have shown that studentfaculty interaction is important for a variety of positive college outcomes among college students (Astin, 1993; Cole, 2007, 2008, 2011; Kim \& Sax, 2009, 2011, 2014; Pascarella \& Terenzini, 2005). Utilizing a statewide college student dataset, this study found that student-faculty interaction is also a significant and positive predictor of select college outcomes for international students. This finding suggests that colleges and universities that serve international students should provide this population with quality experiences that allow frequent and meaningful faculty interactions, both in and out of the classrooms. Similar to their domestic peers, research opportunities, seminars, conferences, and faculty advising can be of particular value for the international student population (Elkins, Forrester, \& Noel-Elkins, 2011).

While this study found that academic engagement, such as studentfaculty interaction and high-order cognitive engagement during class tended to improve international students' gains in select college outcomes, it is also important to note that increased academic effort has a downside. Findings of this study revealed that elevated academic effort is negatively associated with the development of interpersonal skills among international students. In other words, the findings suggest that as international students work harder, they tend to isolate themselves. Academic achievement is one of main reasons that international students attend colleges and universities in the United States (Lee \& Rice, 2007; Mamiseishvili, 2012). Research has identified this achievement-oriented approach to college education sometimes leads to isolation of international students from the campus (AlSharideh \& Goe, 1998; Kim, et al., 2015; Lee, 2010). Therefore, practices, such as study groups or group projects in the classroom, should be more actively used to support not only the academic growth of the international student, but also their affective and interpersonal development during college. Indeed, findings of this study support the use of collaborative learning activities to develop interpersonal skills among international students. Our regression analysis results showed that collaborative work on 
class projects was positively related to interpersonal skills for international students.

\section{LIMITATIONS}

This study was limited in several ways. We used a secondary dataset which presented several distinguishable limitations. The dataset we used was not longitudinal; therefore, we could not measure gains or development over an actual time period but could measure a proxy of the gains or development. That is, to gauge the change in our select college outcome measures, we relied on self-reported information about current and retrospective ability levels when they started at the institution (i.e., as freshman). Given that both the current and retrospective ability levels were collected simultaneously, the change or gains in outcomes assessed in this study may not reflect actual change or gains. In addition, the data was collected from one research university system in California and may not be generalizable to other types of institutions or to institutions in other states. Also, while the dataset used in this study provided a broad range of college experiences and student outcomes that were important to traditional college students, more relevant cultural nuances on college experiences and outcomes for international college population may not have been well-captured by the dataset and may have been overlooked. Another limitation concerns transfer status and their gains over time. Because our sample included a significant amount of transfer students, we felt it was important to include them in our study. However, because transfer students usually start at the institution in their junior year, they are less exposed to institutional experiences than nontransfer students. Therefore, transfer students may not report gains or development at comparable levels as native students. Lastly, international students are not a monolithic group. Smaller groups (e.g. country of origin) would yield more culturally responsive results; however, in the absence of that information, an aggregated analysis of all international students yields important, but limited results.

\section{CONCLUSION AND FUTURE RESEARCH}

International student recruitment is a high priority at many institutions due to the accompanying financial gains. However, this increase in revenue paired with the asymmetrical experiences that international students report in comparison with their domestic peers raises some questions about inequities in the quality of educational experiences and their associated benefits. An implication of our paper and an important trajectory for future research centers on the role of culture in international student success, as well as the importance of reinvesting revenue from international student 
enrollment into programs that facilitate their success. A financial and policy environment that requires revenue from a group of students who do not experience the same benefit as domestic students represents a short-term strategy that will eventually suffer from the recognition of a low quality and expensive education. One strategy to reduce the inequality is to develop a cultural bridge, which connects education with diverse learning experiences (namely, the knowledge brought with students from other countries). Leveraging diverse learning experiences as an important component of the learning environment will potentially acknowledge the value of culture and provide learning gains for all students.

The economic interests of the United States and of higher education institutions remain a primary motivation for attracting international students. However, the results of this study suggest that international students may uniquely experience college and may not benefit from those experiences as much as their domestic peers. Given the propensity of educators to frame negative experiences as issues of personal responsibility for international students, we hope the results of this study will encourage higher education professionals to take notice of the institutional environments and practices that contribute to a more satisfactory and more effective educational experience for international students.

Given the lucrative practice of international student enrollment, additional exploration might protect the educational environment and the overall student experience. In these cases of oversight regarding the educational environment, the students who are not well served are not the only ones who suffer; instead, the entire campus suffers. Altbach and Teichler (2001) highlighted the dangers of international exchange including, "exploitation, either financially or through poor-quality programs...overemphasis on easily marketable products...[,and] neglect of features of learning" (p. 21). International student exploitation is damaging to the educational environment and the purpose of higher education. This study revealed some positive similarities in international and domestic students on two outcomes, but important discrepancies in interpersonal skills and satisfaction. Future studies may focus on how to reproduce the most positive outcomes and dig deeper into discrepancies, even at selective institutions. Attention to the experiences of these students will aid in more than a superficial measure of satisfaction, but will add an overall enhanced learning environment for all students and a prevention of any potential exploitation.

\section{REFERENCES}

Altbach, P. G., \& Teichler, U. (2001). Internationalization and exchange in a globalized university. Journal of Studies in International Education, 5(1), 5-25. 
Astin, A. W. (1993). What matters in college? Four critical years revisited. San Francisco, CA: Jossey-Bass.

Al-Sharideh, K., \& Goe, W. R. (1998). Ethnic communities within the university: An examination of factors influencing the personal adjustment of international students. Research in Higher Education, 39(6), 699-725. doi:10.1023/A:1018714125581

Bartram, B. (2008). Supporting international students in higher education: Constructions, cultures and clashes. Teaching in Higher Education, 13(6), 657-668.

Bauer, K. (1998). Campus climate: Understanding the critical components of today's colleges and universities. New Directions for Institutional Research, 98. San Francisco, CA: Jossey-Bass.

Bevis, T.B. (2002). At a glance: International students in the United States. International Educator, 11(3), 12-17.

Brint, S., Douglass, J., Flacks, R., Thomson, G., \& Chatman, S. (2007). A new generation: Ethnicity, socioeconomic status, immigration and the undergraduate experience at the University of California. Center for Studies in Higher Education, UC Berkeley.

Busseri, M. A., Rose-Krasnor, L., Pancer, S. M., Pratt, M. W., Adams, G. R., BirnieLefcovitch, S., Wintre, M. G. (2010). A longitudinal study of breadth and intensity of activity involvement and the transition to university. Journal of Research on Adolescence, 21, 512-518.

Carini, R., \& Kuh, G. (2003). 2002 NSSE-RAND construct-validation study: Some insights into the role of student engagement to student learning. Bloomington, IN: Indiana University Center for Postsecondary Research.

Chang, M. J., Witt, D., Jones, J., \& Hakuta, K. (2003). Compelling interest: Examining the evidence on racial dynamics in college and universities. Stanford, CA: Stanford University Press.

Chow, P. (2011). What international students think about United States higher education. International Higher Education, 65, 10-12.

Clegg, S., Stevenson, J., \& Willott, J. (2010). Staff conceptions of curricular and extracurricular activities in higher education. Higher Education, 59, 615-26.

Cole, D. (2007). Do interracial interactions matter? An examination of student-faculty contact and intellectual self-concept. The Journal of Higher Education, 78, 249-281.

Cole, D. (2008). Constructive criticism: The role of student-faculty interactions on African American and Hispanic students' educational gains. Journal of College Student Development, 49(6). 587-605.

Cole, D. (2011). Debunking anti-intellectualism: An examination of African American college students' intellectual self-concepts. The Review of Higher Education, 34(2), 259-282.

Edens, D. (2011). Predictors of culinary students' satisfaction with learning. Journal of Hospitality \& Tourism Education, 23(3), 5-15.

Elkins, D. J., Forrester, S. A., \& Noel-Elkins, A. V. (2011). Students' perceived sense of campus community: The influence of out-of-class experiences. College Student Journal, 45(1), 105-121.

Fisher, K. (2012, October 16). Fess up: Foreign students are cash cows. Chronicle of Higher Education

Gellin, A. (2003). The effect of undergraduate student involvement on critical thinking: A metaanalysis of the literature 1991-2000. Journal of College Student Development, 44, 746-762.

Gurin, P., Dey, E. L., Hurtado, S., \& Gurin, G. (2002). Diversity and higher education: Theory and impact on educational outcomes. Harvard Educational Review, 72(3), 330-366.

Harper, S. R., \& Hurtado, S. (2007). Nine themes in campus racial climates and implications for institutional transformation. New Directions for Student Services, 120, 7-24. 
Harper, S. R., \& Quayle, S. J. (2009). Student engagement in higher education: Theoretical perspectives and practical approaches for diverse populations. New York: Routledge.

Hausmann, L. R. M., Schofield, J. W., \& Woods, R. L. (2007). Sense of belonging as a predictor of intentions to persist among African American and White first-year college students. Research in Higher Education, 48(7), 803-839.

Hausmann, L. R. M., Ye, F., Schofield, J. W., Woods, R. L. (2009). Sense of belonging and persistence in White and African American first-year students. Research in Higher Education, 50, 649-669. doi:10.1007/s11162-009-9137-8

Hechanova-Alampay, R., Beehr, T. A., Christiansen, N. D., \& Van Horn, R. K. (2002). Adjustment and strain among domestic and international student sojourners: A longitudinal study. School Psychology International, 23(4), 458-74.

Ho, D. Y. F., \& Ho, R. T. H. (2008). Knowledge is a dangerous thing: Authority relations, ideological conservatism, and creativity in Confucian-heritage cultures. Journal for the Theory of Social Behavior, 38, 67-86

Hurtado, S., Ruiz, A., \& Whang, H. (2012). Assessing students' social responsibility and civic learning. Paper presented at meeting of the Association for Institutional Research, New Orleans, LA.

Institute of International Education (2013). Open doors report on international educational exchange. Retrieved on July 1, 2014 from: http://www.iie.org/Research-andPublications/Open-Doors/Data

Kim, Y. K., Edens, D., Iorio, M., Curtis, C., \& Romero, E. (2015). Cognitive skills development among international students at research universities in the United States. Journal of International Students in Higher Education, 5(4), 526-540.

Kim, Y. K., \& Sax, L. J. (2009). Student-faculty interaction in research universities: Differences by student gender, race, social class, and first-generation status. Research in Higher Education, 50(5), 437-459.

Kim, Y. K., \& Sax, L. J. (2011). Are the effects of student-faculty interaction dependent on major? An examination using multi-level modeling. Research in Higher Education, 52(6), 589-615.

Kim, Y. K., \& Sax, L. J. (2014). The effects of student-faculty interaction on academic selfconcept: Does academic major matter? Research in Higher Education, 55(8), 780809.

Klineberg, O., \& Hull, W.F. (1979). At a foreign university: An international study of adaptation and coping. New York: Praeger.

Kuh, G. D., Kinzie, J., Buckley, J. A., Bridges, B. K., \& Hayek, J. C. (2007). Piecing together the student success puzzle: Research, propositions, and recommendations. ASHE Higher Education Report, 32(5), 1-182. http://doi.org/10.1002/aehe.3205

Lee, J. J. (2010). International students' experiences and attitudes at a United States host institution: Self-reports and future recommendations. Journal of Research in International Education, 9(1), 66-84.

Lee, J. J. (2007). Bottom line-Neo-racism toward international students. About Campus, 11(6), 28-30.

Lee, J. J., \& Rice, C. (2007). Welcome to America? International student perceptions of discrimination. Higher Education, 53(3), 381-409.

Li, D. (2012). Easing transition and promoting a positive student experience within an international partnership scheme for British and Chinese teachers. Journal of Research in International Education, 11(1), 32-49.

Li, W., \& Collins, C. S. (2014). Chinese doctoral student socialization in the United States: A qualitative study. FIRE - Forum for International Research in Education, 1(2), 3257. 
Lopez, M. H., \& Kiesa, A. (2009). What we know about civic engagement among college students. In B. Jacoby (Ed.), Civic engagement in higher education (pp. 31-48). San Francisco, CA: Wiley \& Sons.

Lott II, J. L. (2013). Predictors of civic values: Understanding student-level and institutionallevel effects. Journal of College Student Development, 54(1), 1-16.

Lundberg, C. A., \& Schreiner, L. A. (2004). Quality and frequency of faculty-student interaction as predictors of learning: An analysis by student race/ethnicity. Journal of College Student Development, 45, 549-565.

Mamiseishvili, K. (2012). International student persistence in U.S. postsecondary institutions. Higher Education, 64, 1-17.

McCormick, A., Kinzie, J., \& Gonyea, R. (2013). Student engagement: Bridging research and practice to improve the quality of undergraduate education. In M. B. Paulsen (Ed.), Higher education: Handbook of theory and research (Vol. 28, pp. 47-92): Springer Netherlands.

Mori, S. (2000). Addressing the mental health concerns of international students. Journal of Counseling \& Development, 78, 137-44.

Ostrove, J. M., \& Long, S. M. (2007). Social class and belonging: Implications for college adjustment. The Review of Higher Education, 30, 363-389.

Pascarella, E. T., Ethington, C. A., \& Smart, J. C. (1988). The influence of college on humanitarian/civic involvement values. Journal of Higher Education 59, 412-437.

Pascarella, E. T., \& Terenzini, P. (2005). How college affects students: A third decade of research. San Francisco, CA: Jossey-Bass.

Pritchard, R. M. O., \& Skinner, B. (2002). Cross-cultural partnerships between home and international students. Journal of Studies in International Education, 6(4), 323-54.

Rhee, B. S., \& Dey, E. L. (1996). Collegiate influences on the civic values of students. Paper presented at the annual meeting of the Association for the Study of Higher Education, Memphis, TN.

Rockenbach, A. B. \& Hudson, T. D. \& Tuchmayer, J. B.(2014). Fostering Meaning, Purpose, and Enduring Commitments to Community Service in College: A Multidimensional Conceptual Model. The Journal of Higher Education 85(3), 312338.

Rubin, R. S., Bommer, W. H., \& Baldwin, T. T. (2002). Using extracurricular activity as an indicator of interpersonal skill: Prudent evaluation or recruiting malpractice? Human Resources Management, 41, 441-454.

Sax, L. J. (2000). Citizenship development and the American college student. In T.

Ehrlich (Ed.), Civic responsibility and higher education (pp. 3-18). Westport, CT: The American Council on Education.

Sax, L. J. (2008). The gender gap in college: Maximizing the development potential of women and men. San Francisco, CA: Jossey-Bass.

Schlossberg, N. K., Waters, E. B., \& Goodman, J. (1995). Counseling adults in transition: Linking practice with theory ( $2^{\text {nd }}$ ed.). New York, New York: Springer.

Schreiner, L. A., \& Kim, Y. K. (2011). Outcomes of a Christian college education: A comparison of CCCU students' gains to the national aggregate. Christian Higher Education, 10, 324-352.

Schreiner, L. A., \& Louis, M. (2006). Measuring engaged learning in college students: Beyond the borders of the NSSE. Paper presented at the Association for the Study of Higher Education, Anaheim, CA.

Schreiner, L. A., \& Louis, M. (2008). The engaged learning index: Implications for faculty development. Paper presented at the annual meeting of the Association for the Study of Higher Education, Jacksonville, FL.

Strauss, L. C., \& Volkwein, J. F. (2004). Predictors of student commitment at two-year and four-year institutions. Journal of Higher Education, 75, 203-207. doi:10.1353/jhe.2004.0007. 
Strayhorn, T. L. (2012). College students sense of belonging: A key to educational success for all students. New York, NY: Routledge.

Suhre, C. J. M., Jansen, E. P. W. A., \& Harskamp, E. G. (2007). Impact of degree program satisfaction on the persistence of college students. Higher Education: The International Journal of Higher Education and Educational Planning, 54(2), 207226. http://doi.org/10.1007/s10734-005-2376-5

Tieu, T. T., \& Pancer, S. M. (2009). Youth involvement and first year students' transition to university: Quality vs. quantity of involvement. Journal of the First-Year Experience and Students in Transition, 21, 43-64.

Tieu, T. T., Pancer, S. M., Pratt, M. W., Wintre, M. G., Birnie-Lefcovitch, S., Polivy, J., \& Adams, G. (2010). Helping out or hanging out: The features of involvement and how it relates to university adjustment. Higher Education, 60, 343-55.

Umbach, P. D., \& Wawrzynski, M. R. (2005). Faculty do matter: The role of college faculty in student learning and engagement. Research in Higher Education, 46(2), 153184. doi:10.1007/s11162-004-1598-1

Volkwein, J. F., Valle, S., Parmely, K., Gary, B., \& Zhou, Y. (2000). A muliti-campus study of academic performance and cognitive growth among native freshman, two-year transfers, and four-year transfers. Paper presented at the Annual Forum of the Association for Institutional Research, Cincinnati, OH.

Vowell, F. (2007). Engaging faculty to foster student development. In G. L. Kramer (Ed.), Fostering student success in the campus community (pp. 318-342). San Francisco: Jossey-Bass.

Zhao, C., Kuh, G. D., \& Carini, R. M. (2005). A comparison of international student and American student engagement in effective educational practices. Journal of Higher Education, 76, 209-231.

\section{Appendix A. Variable Definitions and Coding Schemes}

\begin{tabular}{ll}
\hline \multicolumn{1}{c}{ Variables } & \multicolumn{1}{c}{ Coding Schemes } \\
\hline Outcome Measures & Factor (range from 2 to 6$)^{*}$ \\
Cognitive outcomes scale & Likert scale: $1=$ very poor, $6=$ excellent \\
Interpersonal skills & Factor (range from 2 to 6$)^{*}$ \\
Civic attitudes scale & Factor (range from 1 to 6$)^{*}$ \\
Pretest Measures & Likert scale: $1=$ very poor, $6=$ excellent \\
Freshman cognitive outcomes scale & Factor (range from 1 to 6$)^{*}$ \\
Freshman interpersonal skills & \\
Freshman civic attitudes scale & $0=$ female, $1=$ male \\
Student Background Characteristics & All dichotomous: $0=$ no, $1=$ yes \\
Gender & $0=$ Native student, $1=$ Upper division \\
Socioeconomic status (Ref: Professional class/wealthy) \\
$\quad$ Working class/Low-income & transfer student \\
Middle-class & $0=$ High school diploma or less, \\
Transfer Status & $1=$ AA degree or more \\
& $0=$ English not native language, \\
Parental education level & $1=$ English native language \\
& \\
Language heritage & All dichotomous: $0=$ no, $1=$ yes \\
&
\end{tabular}


Quality of instruction and courses in the major

Satisfaction with advising and out-of-class contact

Academic engagement with faculty

Involved in faculty research projects

Critical reasoning classroom activity

Curricular foundation for reasoning

Elevated academic effort

Participated in clubs or organizations

Collaborative work on class project
Factor (range 0 to 9$)^{\dagger}$

Factor (range 0 to 10$)^{\dagger}$

Factor (range 1 to 6 )

$0=$ no involvement, $1=$ some

involvement

Factor (range 0 to 9$)^{\dagger}$

Factor (range 0 to 8 ) ${ }^{\dagger}$

Factor (range 0 to 9$)^{\dagger}$

$0=$ no participation,

$1=$ participation

Likert scale: $1=$ never, $6=$ very often

*See Table 1 for information on factor loadings and internal reliability on outcomes/pretest factor scales.

${ }^{\dagger}$ See Appendix B for information on factor loadings and internal reliability

\section{Appendix B. Factor Loadings and Internal Reliability on Factor Scales}

\begin{tabular}{lcc}
\hline Factor and Survey Items & Factor \\
Loading & $\begin{array}{c}\text { Internal Con- } \\
\text { sistency }(\alpha)\end{array}$ \\
\hline
\end{tabular}

Satisfaction with the Quality of Instruction and Courses .76 in Major*

How satisfied are you with each of the following aspects of your educational experience in the major?

(Likert scale: 1 =very dissatisfied, $6=$ very satisfied)

Quality of lower-division courses in your major

Quality of upper-division courses in your major

Quality of faculty instruction

Quality of teaching by graduate student TA's

Satisfaction with Advising and Out-Of-Class Contact

How satisfied are you with each of the following aspects of your educational experience in the major?

(Likert scale: 1 =very dissatisfied, $6=$ very satisfied)

Advising by faculty on academic matters $\quad .78$

Advising by student peer advisors on academic $\quad .70$

matters

Advising by school or college staff on academic $\quad .78$

matters

Advising by departmental staff on academic mat-

ters

Please answer the following questions about your

major (Dichotomous: 1=yes, 2=no):

Are there open channels of communication be-

tween faculty and students?

Are students treated equitably and fairly by facul-

ty?

Do faculty provide prompt and useful feedback

on students work? 
$1=$ never, $6=$ very often)

Talked with the instructor outside of class about issues and concepts derived from a course

Interacted with faculty during lecture class sessions

Communicated with a faculty member by email or in person

Worked with a faculty member on an activity other than coursework

Taken a small research-oriented seminar with faculty

Critical Reasoning Classroom Activity*

Thinking back on this academic year, how often have you REQUIRED to do the following? (Likert scale:

1 =never, 6 =very often)

Judge the value of information, ideas, actions and conclusions based on the soundness of sources, methods and reasoning

Create or generate new ideas, products or ways of understanding

Thinking back on this academic year, how often have you done each of the following? (Likert scale:

$1=$ never, $6=$ very often)

Used facts and examples to support your viewpoint

Incorporated ideas or concepts from different courses when completing assignments

Examined how others gathered and interpreted data and assessed the soundness of their conclusions

Reconsidered your own position on a topic after assessing the arguments of others

Curricular Foundation for Reasoning*

Thinking back on this academic year, how often have you REQUIRED to do the following? (Likert scale:

$1=$ never, $6=$ very often)

Recognize or recall specific facts, terms and concepts

Explain methods, ideas, or concepts and use them to solve problems

Break down material into component parts or arguments into assumptions to see the basis for different outcomes and conclusions

Elevated Academic Effort*

How frequently during this academic year have you done each of the following? (Likert scale: $1=$ never, $6=$ very often)

Raised your standards for acceptable effort due to the high standards of a faculty member

Extensively revised a paper at least once before submitting it to be graded

Factor scale was developed by the Center for Studies in Higher Education, UC Berkeley. 


\section{Authors' Note}

The authors presented an earlier version of this paper at the annual meeting of the American Educational Researcher Association, Chicago, IL, in April 2015.

YOUNG K. KIM, Ph.D., is an associate professor in the Department of Higher Education at Azusa Pacific University. She received her Ph.D. in Higher Education at the University of California, Los Angeles. Her research interests include college student development, conditional effects of college experience, and diversity and educational equity in higher education. Dr. Kim has published in prestigious peer-reviewed journals in the field of higher education, including Research in Higher Education and The Review of Higher Education. Email: YKKim@apu.edu

CHRISTOPHER S. COLLINS, Ph.D., is assistant professor of Higher Education at Azusa Pacific University. His research interests include the role of higher education related to poverty reduction, knowledge extension, public good, and social rates of return. Recent publications include Higher Education and Global Poverty: University Partnerships and the World Bank in Developing Countries (Cambria Press, 2011) and Education Strategy in the Developing World: Revising the World Bank's Education Policy Development (Emerald Publishing, 2012). In addition, he has published articles in The Review of Higher Education, Higher Education, and the Journal of Higher Education. Email: CCollins@apu.edu

LIZ A. RENNICK is a research and assessment analyst at the University of Arizona, as well as a doctoral student and graduate research assistant in the Department of Higher Education at Azusa Pacific University. Her research addresses equity and opportunity in higher education, community college students, transfer students, and Latino college students. Email: lizarennick@gmail.com

DAVID EDENS, Ph.D., is a lecturer in the Human Nutrition and Food Science at Cal Poly Pomona. He received his Ph.D. in Higher Education at Azusa Pacific University. His research has focused on student success and learning among diverse student populations including international students, non-traditional students, and students attending for-profit colleges and universities. Dr. Edens has presented at conferences such as AERA and CSRDE, as well as published for Noel-Levitz and in the Journal of Hospitality \& Tourism Education. Email: Dredens@cpp.edu 